\title{
Are sun- and shade-type anatomy required for the acclimation of Neoregelia cruenta?
}

\author{
FERNANDA REINERT ${ }^{1,2}$, MARCOS V. LEAL-COSTA ${ }^{3}$, \\ NÍCIA E. JUNQUEIRA ${ }^{4}$ and ELIANA S. TAVARES ${ }^{1,2}$ \\ ${ }^{1}$ Departamento de Botânica, Instituto de Biologia, Universidade Federal do Rio de Janeiro, Av. Carlos Chagas Filho, 373 , \\ Edifício do Centro de Ciências da Saúde, Sala A1-102, Bloco A, Ilha do Fundão, 21941-902 Rio de Janeiro, RJ, Brasil \\ ${ }^{2}$ Programa de Pós-Graduação em Biotecnologia Vegetal, Universidade Federal do Rio de Janeiro, \\ Av. Carlos Chagas Filho, 373, Sala K2-32, Bloco K, Edifício do Centro de Ciências da Saúde, \\ Ilha do Fundão, 21941-902 Rio de Janeiro, RJ, Brasil \\ ${ }^{3}$ Instituto Federal de Educação, Ciência e Tecnologia Fluminense, \\ Rua Dr. Siqueira, 273, Parque Dom Bosco, 28030-130 Campos dos Goytacazes, RJ, Brasil \\ ${ }^{4}$ Consórcio CEDERJ, Rua Marechal Deodoro, 117, Centro, 25802-220 Três Rios, RJ, Brasil \\ Manuscript received on April 5, 2011; accepted for publication on October 28, 2011
}

\begin{abstract}
Sun and shade plants are often discriminated by a number of sun- and shade-type anatomies. Nonetheless, we propose that among tank-bromeliads, changes in rosette architecture satisfy the requirements for coping with contrasting light levels. The tank-bromeliad Neoregelia cruenta naturally colonises sub-habitats ranging from full exposure to direct sunlight, to shaded environments in sand ridge plains. We quantified anatomical and morphological traits of leaves and rosettes of $N$. cruenta grown under sun and shade conditions. Cells with undulated lateral walls within the water parenchyma are for the first time described for the family. Under high light, leaf blades were wider, shorter, and yellowish. The rosette diameter of sun plants was less than half that of shade plants. Sun leaves overlapped with neighbouring leaves for most of their length, forming a cylindrical rosette where water accumulates. Shade leaves only overlapped in the centre of the rosette. Most anatomical traits were similar under both growth conditions. Stomata were absent from the base of sun leaves, which is probably explained by limited gas exchange at the base of the tight sun-type rosette. Data suggest that the ability of $N$. cruenta to acclimate to sun and shade is better explained by changes in rosette architecture than by leaf anatomy.
\end{abstract}

Key words: Bromeliaceae, crown architecture, leaf anatomy, plant morphology.

\section{INTRODUCTION}

The understory vegetation of tropical rainforests shows large variation in leaf morphology and crown architecture (Bongers and Popma 1990, Valladares et al. 2000, 2002). Crown architecture with minimum leaf overlapping in the horizontal plane minimizes

Correspondence to: Fernanda Reinert

E-mail: freinert@biologia.ufrj.br self-shading and, therefore, maximizes capture of photosynthetic active radiation (PAR), an expected feature among shade plants (Pearcy and Yang 1998, Valladares et al. 2000, 2002). Plant acclimation to environments with contrasting PAR levels involves physiological and morphological modifications including: leaf gas exchange, absorptance and reflectance properties, pigment composition and 
crown architecture (Kohyama and Hotta 1990, Poorter et al. 2000, Valladares et al. 2000, 2002, Scarano et al. 2002, Mantuano et al. 2006). Sun plants generally have higher photosynthetic capacity on a leaf area basis, thicker leaves and higher nitrogen content. In contrast, plants in shaded habitats show minimum leaf overlap, higher chlorophyll content, thinner mesophyll tissue, and less stomata on a leaf area basis (Björkman 1981, Givnish 1988, StraussDebenedetti and Berlyn 1994).

Within Bromeliaceae, although there have been a large number of studies on physiological responses to varying PAR (Martin 1994, Reinert et al. 2001, Fernandes et al. 2002, Haslam et al. 2002), only a few explore sun and shade anatomical and morphological characteristics of the rosettes. The studies on Tillandsia usneoides under three incident light levels (Martin et al. 1985); and the ones on Bromelia humilis and Aechmea bromeliifolia under natural contrasting environments (Lee et al. 1989, Scarano et al. 2002, respectively) suggest that, at least for some characters, the results are conflicting. For example, the number of stomata reduces in response to higher PAR in T. usneoides but can either increase or decrease in A. bromeliifolia when different light levels are associated with other environmental variants. Additionally, Bromeliaceae have a large number of species with the CAM (Crassulacean Acid Metabolism) photosynthetic pathway which is often associated with particular anatomical traits. A general feature of CAM plants is leaf succulence, characterized by large undifferentiated mesophyll cells with large vacuoles and relatively reduced intercellular air space (Gibson 1982, Winter et al. 1983, Smith et al. 1996, Nelson et al. 2005, Nelson and Sage 2008).

Besides possible anatomical variation in response to sun and shade conditions or in relation to the presence of CAM, members of the subfamilies Bromelioideae and Tillandsioideae show very diverse life forms: including atmospheric forms and the tank-forming rosettes. Both forms have highly specialized scales to the acquisition of water and nutrients, the stalked peltate trichomes, which were well described by Benzing (1970, 1976). Atmospheric bromeliads have non-absorptive roots that are associated with holding the plant to the substrate, often trunks and wires (Martin 1994). Tank-forming rosettes are characterized by wide, flat leaves with expanded overlapped bases forming separate water impounding chambers, known as tanks, within which water and debris are held.

The occurrence of C3 and CAM species, of different life forms and species distributed over a wide range of environments make the Bromeliaceae a group of particular interest for many research areas (Lee et al. 1989, Martin 1994, Scarano et al. 2002). Neoregelia cruenta (R. Graham) L.B. Smith is a CAM and tank-forming bromeliad widely distributed in the sand ridge plains of Rio de Janeiro, Brazil, known as restingas (Lacerda and Hay 1982 , Reinert et al. 1998). This species occurs in a variety of microhabitats; from the understory of the restinga forest to bare sand under full exposure. Neoregelia cruenta shows a wide variety of morphotypes, from short well overlapped yellowish leaves in the sun to long thin dark leaves in the shade (Fig. 1; Reinert et al. 2001, Fernandes et al. 2002). Despite being found over a wide range of PAR, vapour pressure deficits and different exposure to salt spray, $N$. cruenta seedlings relative to other bromeliads such as members of the Tillandsoideae subfamily are very vulnerable to water loss (Mantovani and Iglesias 2005). One of the reasons that partially explains the vulnerability of $N$. cruenta seedlings to desiccation is the fact that trichomes only appear after the $11^{\text {th }}$ day upon germination (Mantovani and Iglesias 2005). Changing crown architecture and leaf characteristics seem to be the core of this species' ability to inhabit the deep understory forest all the way to the coast line. Here we describe morphological and anatomical traits of the rosettes of $N$. cruenta grown under sun and shade conditions. 


\section{MATERIALS AND METHODS}

Field work was conducted in the restinga of Barra de Maricá, $40 \mathrm{~km}$ from the city of Rio de Janeiro (22 52'S e 42 52'W) in September 2008. For the characterization of the architecture of sun and shade rosettes of $N$. cruenta, measurements were taken in five fully exposed plants and five shaded ones: plant height; plant diameter 1 and $2\left(90^{\circ}\right.$ to each other); tank height (from the base to the point where leaves stop overlapping); and number of leaves. From each of the measured plants, one completely expanded and non senescing leaf $\left(5^{\text {th }}\right.$ or $6^{\text {th }}$ leaf counting from the centre of the tank) was removed for morphoanatomical studies. Leaf length and leaf basal width were measured to estimate leaf area. Leaves were cut in three equivalent portions for the anatomical studies: the leaf base, leaf middle and the leaf apex were fixed in $70 \%$ alcohol. Previous measurements of light levels showed that the exposed sites get 3 to 10 times more light than the shade sites depending on the time of the day and the season.

Transversal sections from the three portions (base, middle and apex) were made with a manual Ranvier microtome and stained with a mixture of Safranine and Astra Blue (Bukatsch 1972). Observations, measurements and photographs were taken under an optical microscope (Zeiss Axioskop 2, DEI-750 D, CE, Germany) using magnification lenses of 5, 10, 20 and 40x equipped with a video, a digital camera (Optronics, USA), and a computer with a Windows ${ }^{\circledR}$ compatible program (Axiovision 3.0, USA). The following measurements were taken from each portion (base, middle and apex) of sun and shade leaves: thickness of the leaf, epidermis (including the hypodermis), chlorophyll parenchyma, and water parenchyma; and the vascular bundles frequency in one linear millimeter. Measurements were taken from five replicates from each of the five sun and shade leaves $(n=25)$. All measurements in transversal view were taken avoiding the depression region around the trichome stalks. Epidermal peels were obtained and stained with Jeffrey's technique (Kraus and Arduin 1977) to characterize the epidermis from frontal view and to determine the number of stomata and trichomes per surface area. Measurements were done by projection of slides onto $1 \mathrm{~mm}^{2}$ graph paper with the aid of a lucid chamber connected to an optical microscope (Zeiss Standard, Germany). Characterization of the trichomes was done by gently scraping leaf surfaces. Trichomes were stained with Safranine and Astra Blue. All slides were mounted in a mixture of water and glycerine $(1: 1 \mathrm{v} / \mathrm{v})$ and sealed with colourless nail polish.

Statistical analyses were undertaken with the aid of the software Graph Pad Instat 3.0 for Windows ${ }^{\circledR}$. Mean values within each region (base, middle and apex from both abaxial and adaxial side) were compared by the T test. Differences between means were considered significant at $\mathrm{p}<0.05$.

\section{RESULTS}

The upper surface of Neoregelia cruenta leaves vary from dark green to yellowish and appear shiny and smooth, whereas the lower surface is whitish with longitudinal parallel ridges and white lines across. Different phenotypes, displaying the full range of characteristics, are naturally found in the restinga within a few meters of each other depending on the degree of shading. Rosette and leaf morphological parameters for sun and shade plants are shown in Table I. Tank height (comprising the base of the rosette that withholds water due to overlapping of the leaf bases) was nearly three times higher in sun plants. Shade leaves are narrower, about twice as long and have almost two times more chlorophyll than sun leaves. Thorns are present on the lateral border of both sun and shade leaves (Fig. 2). In sun plants, thorns are closer together, reddish, larger and harder, and the top end of the tank coincides with the appearance of the first thorns. In shade plants, flexible and transparent thorns less than $1 \mathrm{~mm}$ in length can be distinguished from the very basal portion of the leaves (Fig. 2; Tab. I). 
TABLE I

Morphological measurements of the rosettes and leaves of shade and sun plants of Neoregelia cruenta.

\begin{tabular}{lcc}
\hline & Shade & \multicolumn{1}{c}{ Sun } \\
\hline Plant height & $55.0 \pm 4.75^{*}$ & $33.2 \pm 1.53^{*}$ \\
Plant diameter 1 & $78.8 \pm 7.87^{* *}$ & $32.6 \pm 1.57^{* *}$ \\
Plant diameter 2 & $67.2 \pm 8.78^{*}$ & $28.2 \pm 1.59 *$ \\
Tank height & $7.4 \pm 1.20^{* *}$ & $20.8 \pm 1.32^{* *}$ \\
Number of leaves & $10.8 \pm 1.16^{*}$ & $16.6 \pm 1.29 *$ \\
Leaf length & $55.8 \pm 3.67 * *$ & $27.4 \pm 0.93^{* *}$ \\
Leaf base width & $7.8 \pm 0.37^{* * *}$ & $10.4 \pm 0.24 * * *$ \\
Leaf area & $421.2 \pm 28.07^{* *}$ & $278.4 \pm 7.90^{* *}$ \\
Total chlorophyll & $388.9 \pm 23.70^{* * *}$ & $183.4 \pm 9.70^{* * *}$ \\
Number of thorns & $4.2 \pm 0.33^{*}$ & $5.5 \pm 0.50^{*}$ \\
(40mm) & & \\
Distance between & $10.8 \pm 1.39^{* *}$ & $5.21 \pm 0.52^{* *}$ \\
thorns & & \\
Height of the thorn & $0.763 \pm 0.04^{* * *}$ & $2.28 \pm 0.25^{* * *}$ \\
Base of the thorn & $0.512 \pm 0.03^{* * *}$ & $1.15 \pm 0.13^{* * *}$ \\
\hline
\end{tabular}

Mean values \pm standard error $(\mathrm{n}=5)$.

$* \mathrm{p}<0.05 * * \mathrm{p}<0.001 ; * * * \mathrm{p}<0.0001$.
Frontal view: the epidermal cells are rectangular with wavy anticlinal walls (Fig. 3A, B). Trichomes are present on both surfaces. Trichomes are composed of central cells surrounded by a wing of cells. However not all trichomes are clearly concentric (Fig. 3C, D). Trichome shields are visually larger on the leaf base than on the middle and apex in sun and shade plants (Fig. 3C, D). The number of trichomes significantly varied between shade and sun leaves in the three portions in both adaxial and abaxial sides (Tab. II). Stomata are tetracitic and only present on the abaxial surface. They are shaded by trichomes oriented in series with the long axis of the guard cells parallel to the long axis of the leaf. Stomata are almost entirely absent at the base of the sun leaves.

Transversal sections: sun leaves are significantly thicker in the apex and thinner in the base than shade leaves (Tab. II). The epidermis is a single layer of flat cells highly lignified. The cuticle is too thin

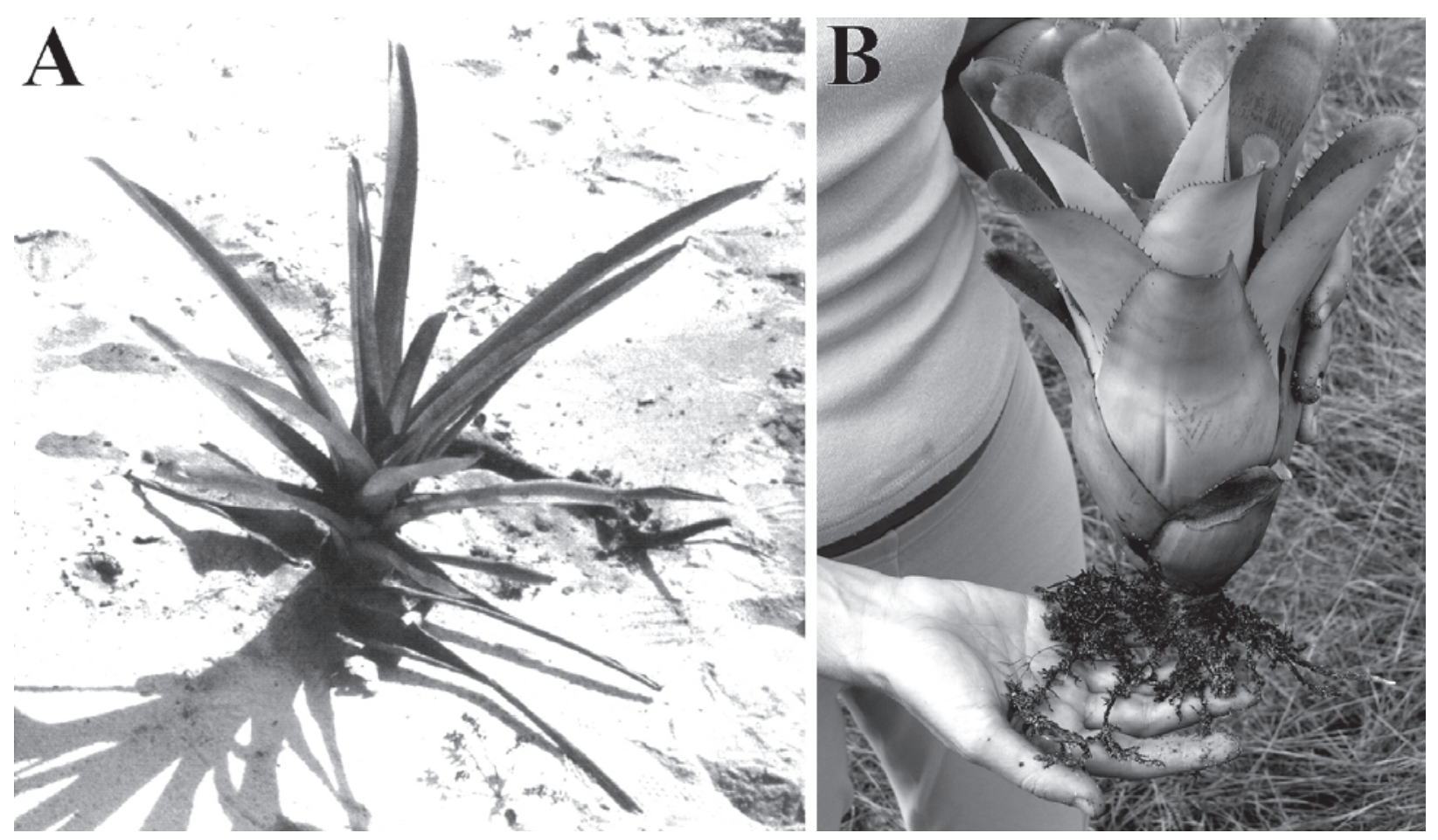

Figure 1 - Shade (A) and sun (B) rosettes of Neoregelia cruenta under natural conditions.

Note differences in the rosette architecture. 
TABLE II

Anatomical parameters in three portions of shade and sun leaves of Neoregelia cruenta.

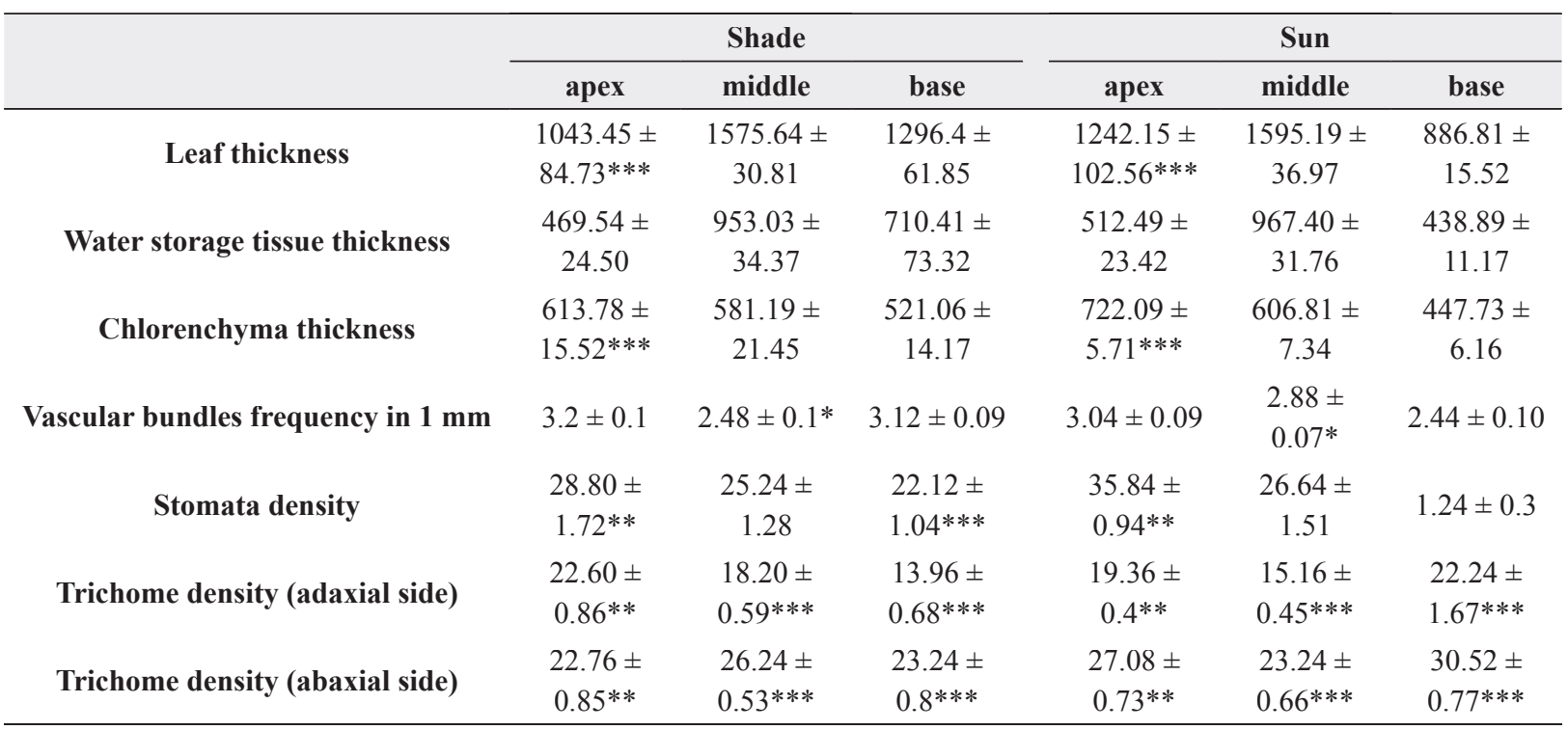

Mean values \pm standard error $(\mathrm{n}=25) .{ }^{*} \mathrm{p}<0.05 * * \mathrm{p}<0.001 ; * * * \mathrm{p}<0.0001$.
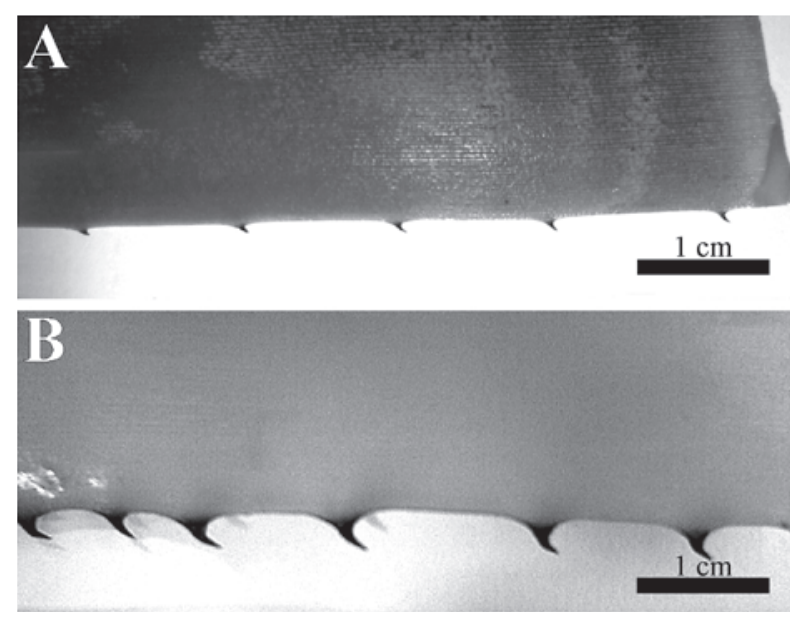

Figure 2 - Leaf thorns of shade (A) and sun (B) plants.

to be discerned at these magnifications (Fig. 4A, B). Stomata and trichomes are in depressions of the epidermis (Fig. 4C, D). Trichomes are composed of a stalk with 3-4 cells and a wing with varying number of cells. Below the epidermis there are one or two layers of strongly lignified cells. Below these sub-epidermal layers, there is a water storage colourless parenchyma with varying number of cell layers and cell shapes depending on the region of the leaf (Fig. 5). The water parenchyma also has cells with undulant lateral walls that resemble a concertina (Fig. 6). Sun plants show five to six layers of cells in the water parenchyma, they are isodiametric and somewhat dorso-ventrally flat in the leaf base, and isodiametric in the leaf apex (Fig. 5). In the leaf middle of sun plants, the water parenchyma includes cells of two different shapes: about three layers of isodiametric cells and three layers of approximately cylindrical anticlinally elongated cells (Fig.5). In shade plants, the water parenchyma has seven to nine layers of isodiametric and dorso-ventrally elongated cells in the base and in the middle of the leaves; and five to seven layers of isodiametric cells in the leaf apex. Below the water parenchyma, there is the densely packed chlorenchyma tissue. In sun plants, similarly to what is found for the water parenchyma, cells are isodiametric and somewhat dorso-ventrally flat in the leaf base and middle, and more elongated cells in the leaf apex. The number of cell layers varies around 14 in the leaf base, 18 in the leaf middle and 23 in the leaf apex. Overall, shade leaves show 

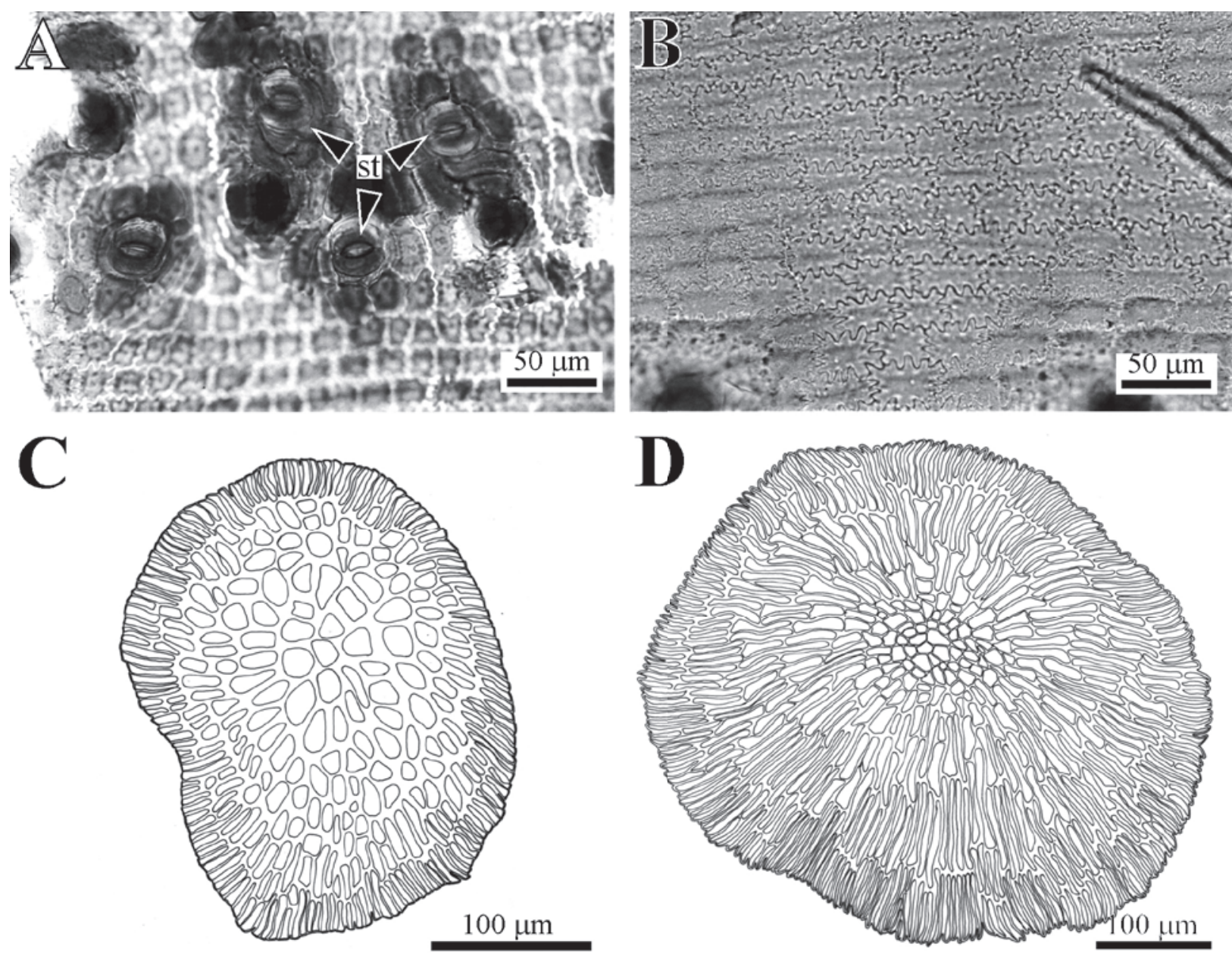

Figure 3 - Epidermis of Neoregelia cruenta in frontal view. (A) abaxial surface of a shade plant plant, (B) adaxial surface of a sun plant, (C) Drawing of a trichome from the middle portion, (D) Drawing of a trichome from the leaf base. st - stomata.

similar shape cells, however, the number of cell layers in the leaf middle varies between 18 and 22 and in the apex between 16 and 21. At the base, the number of cell layers was equivalent to that of sun leaves (14) (Fig. 7). In sun leaves the chlorenchyma is significantly thicker in the apex and thinner in the base compared to shade leaves (Tab. II). The chlorenchyma and the sub-epidermal tissues are interrupted by stomatal chambers (Fig. 7).

The collateral vascular strands run the length of the leaves between the chlorenchyma (Fig. $8 \mathrm{~A}, \mathrm{~B})$. The costal chlorenchyma buttresses the bundle sheaths (Fig. 8A, B). The vascular bundles are surrounded by sclerenchyma cells that may extend towards both surfaces (Fig. 8A, B). The vascular bundles with the ensheathing fibres differ in size and generally alternate larger with one or more smaller ones (Fig. 8A, B). Aerial channels, filled with arm-like cells, are observed between the vascular bundles. This tissue is loosely packed and forms a trabeculae system which supports the aerial channels (Fig. 8C-E). Transversal vascular bundles, or commissures, cross the aerial channels connecting the main longitudinal bundles (Fig. 8D). Near these bundles, the arm-like parenchyma is more densely packed. The vascular bundles frequency in one linear millimeter in shade plants is equivalent in both plants (Tab. II). 

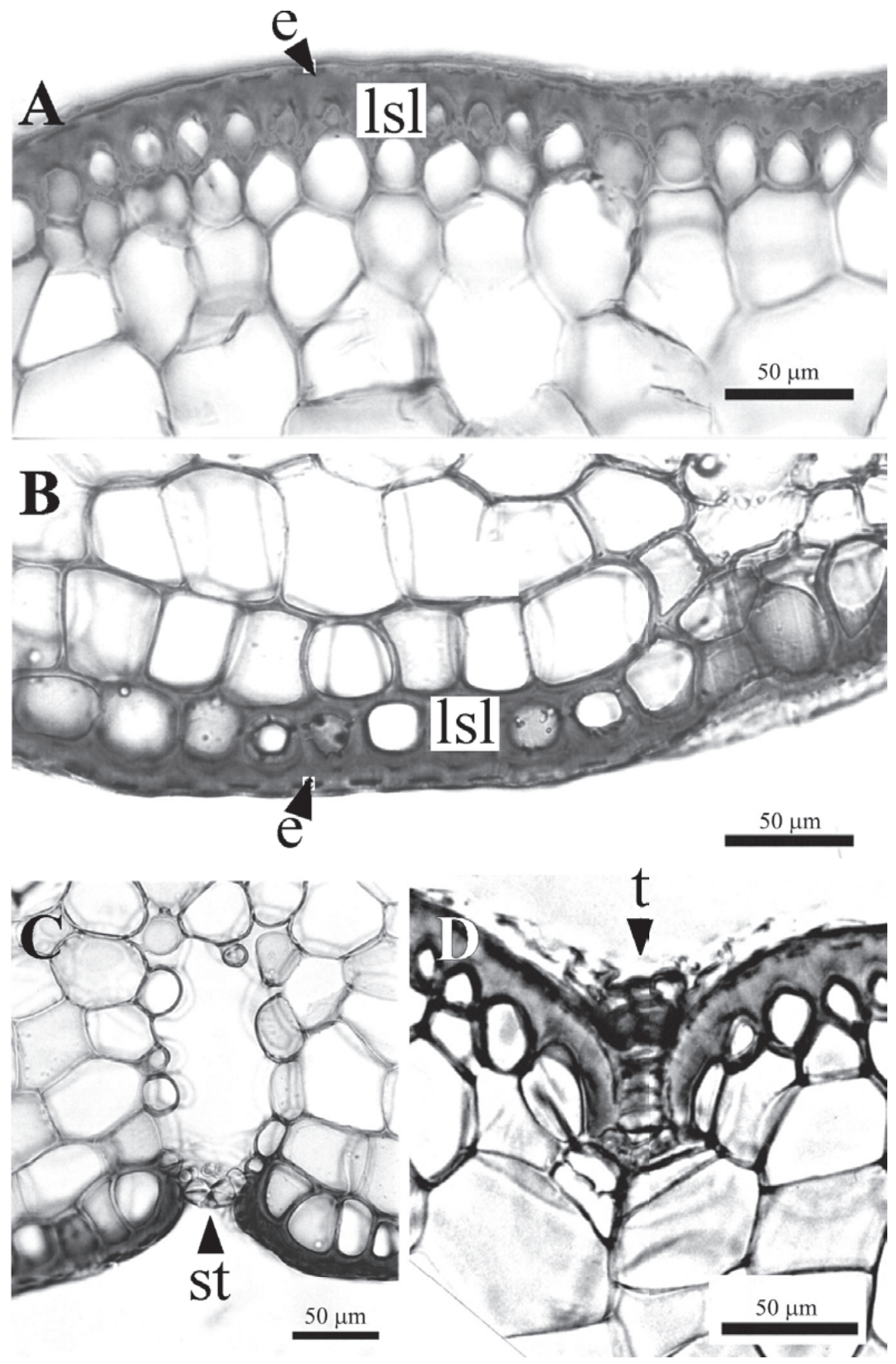

Figure 4 - Epidermis of Neoregelia cruenta in transversal view. (A) adaxial surface, (B) abaxial surface, (C) detail of stoma and stomatic chamber, (D) detail of adaxial trichome. e - epidermis, lsl - lignified subepidermal layer, st - stoma, $\mathrm{t}$ - trichome. 
A $\quad$ B $\quad$ C

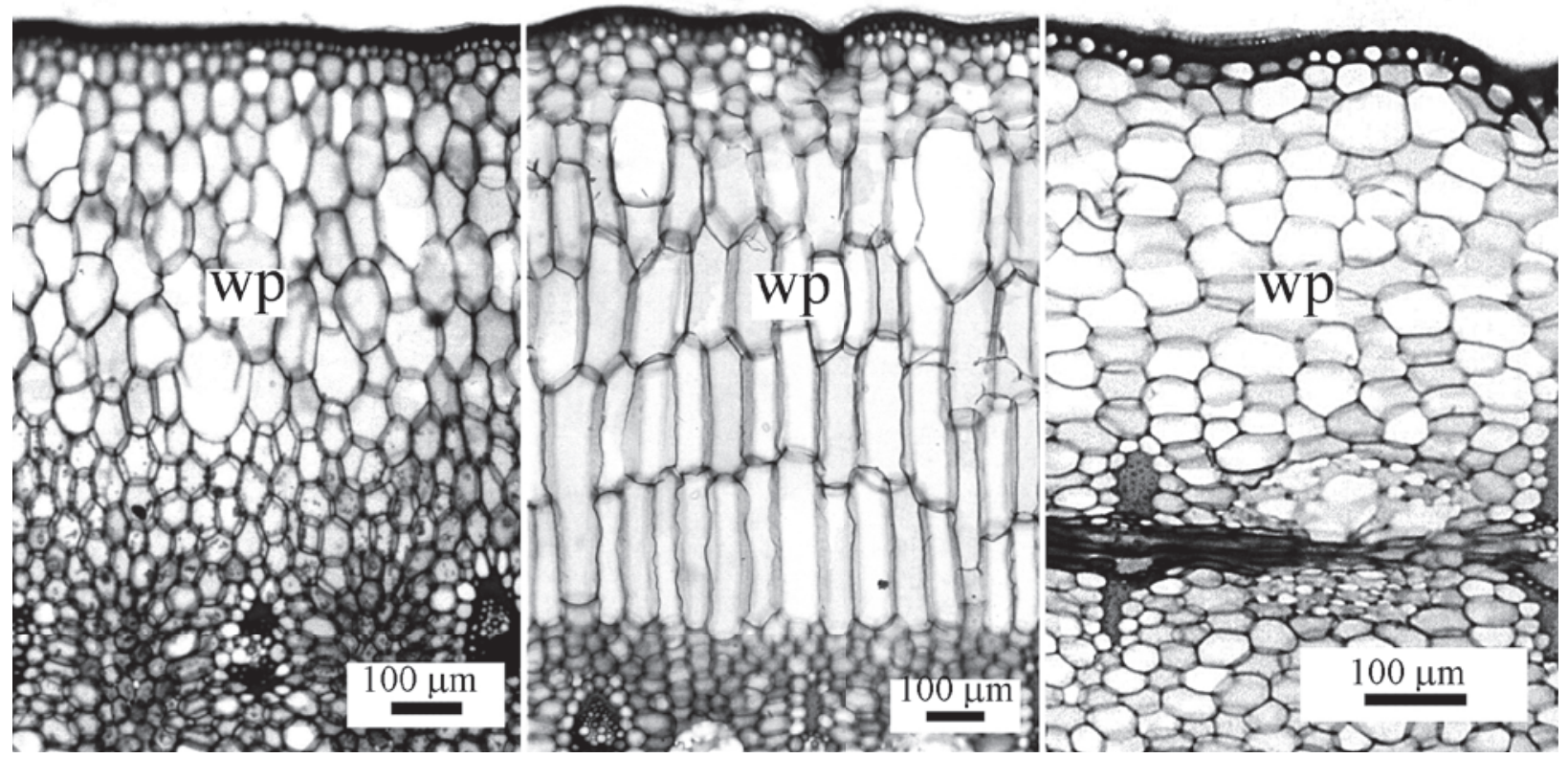

Figure 5 - Transversal sections of Neoregelia cruenta leaves showing water storage parenchyma (wp) in base (A) middle (B) and apex (C).
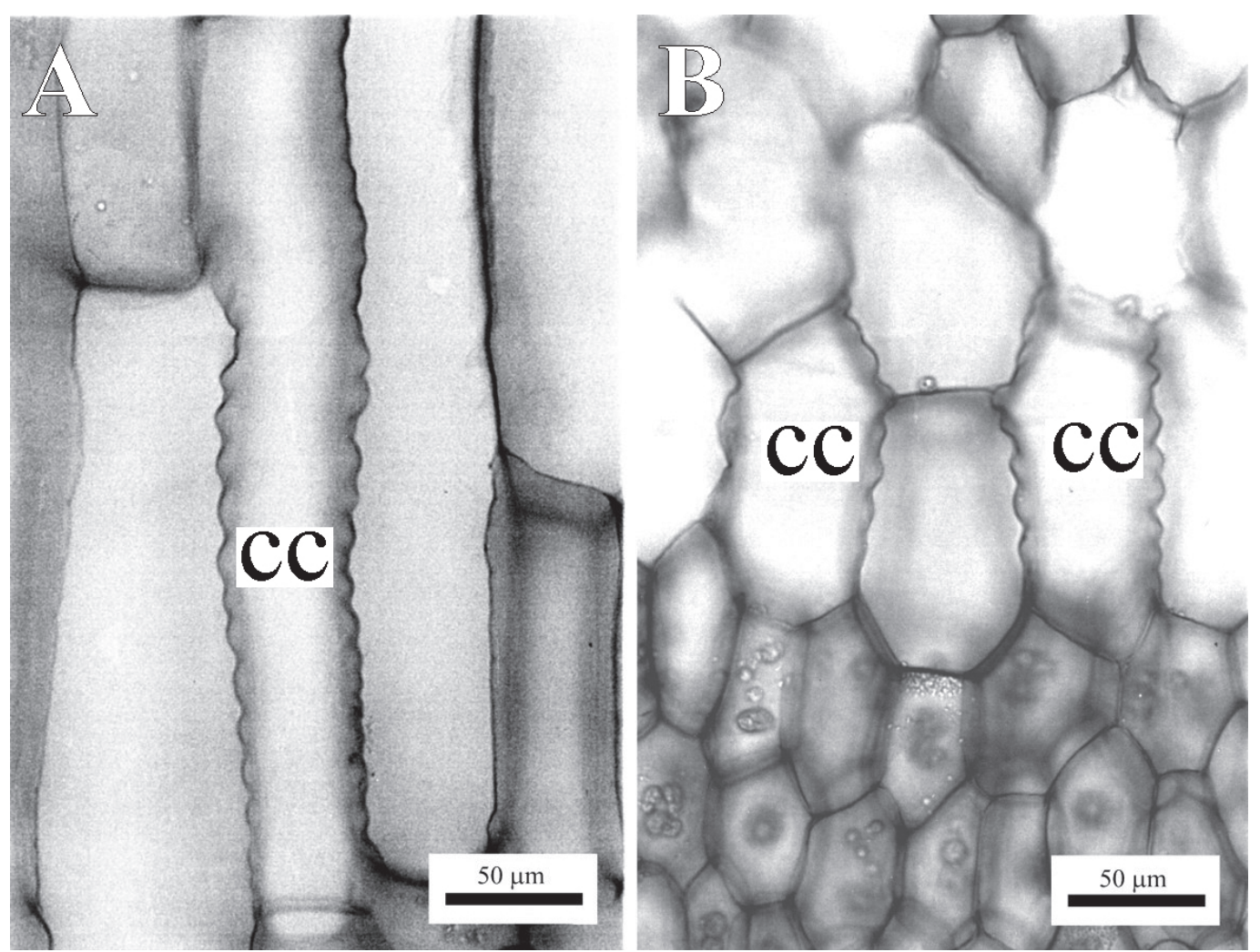

Figure 6 - Detail of Neoregelia cruenta water storage parenchyma showing concertina-like cells (cc). At middle portion $(\mathbf{A})$ and apex (B). 


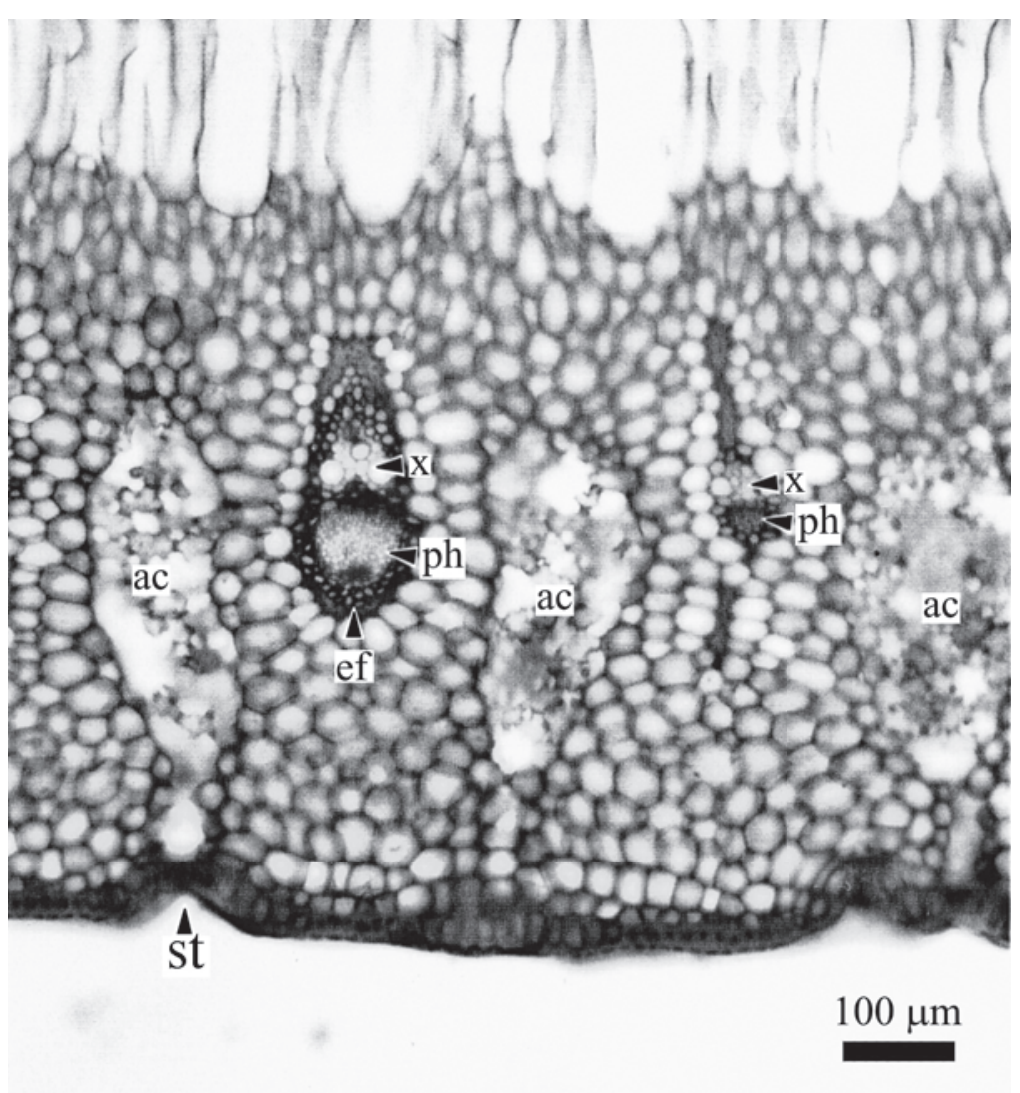

Figure 7 - Transversal section of Neoregelia cruenta leaf, in detail the chlorenchyma tissue, vascular bundles and aerial channels. ac - aerial channel, ef - ensheathing fiber, ph - phloem, st - stoma, x - xylem.

\section{DISCUSSION}

Most morphological attributes of the rosette quantified here for shade and sun plants differed statistically. Similar morphological variation of the rosette was described for Bromelia humilis under several shading levels (Lee et al. 1989). The striking morphological plasticity observed among several bromeliad species is believed to be mainly a response to light (Lee et al. 1989, Martin 1994). Indeed sun plants, which are easier to handle because of the compact rosette, were transferred to a tropical greenhouse in the north of England for a previous study, and the result was: younger leaves and newborn ones developed shade traits while old sun leaves senesced. The rosette attributes became that of a typical shade plant observed in the field (R. Reinert, personal observations).
The main anatomical characteristics of $N$. cruenta are similar to those described for other Bromeliaceae family members (Tomlinson 1969, Loeschen et al. 1993, Reinert and Meirelles 1993, Proença and Sajo 2004, Scatena and Segecin 2005, Proença and Sajo 2007). The highly lignified sub-epidermal layer(s) was described for several genera such as Neoregelia, Ananas and Bromelia (Tomlinson 1969). As the ontogeny of this tissue was not studied here, it is not possible to state whether this sub-epidermal tissue is a hypodermis, as described for other bromeliad species (Tomlinson 1969) or if it is derived from the epidermis and, therefore, it is a multiple epidermis. The absence of palisade tissue is known among Bromeliaceae; of the 22 species studied by Downs (1974), five have this tissue. To the best of our knowledge, concertina 

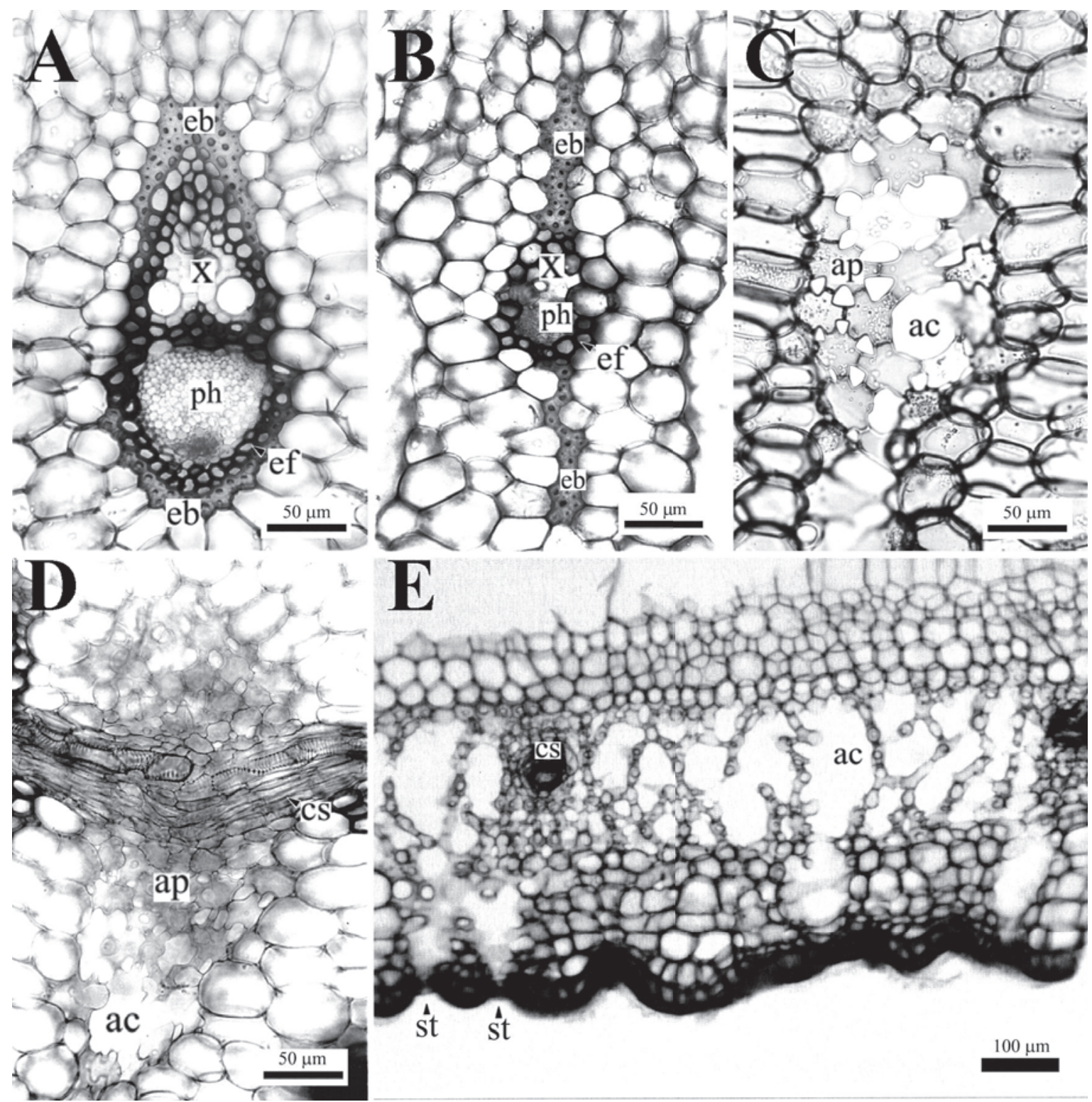

$100 \mu \mathrm{m}$

Figure 8 - Details of vascular bundles and aerial channels. (A) large vascular bundle, (B) small vascular bundle, (C) transversal view of aerial channel showing the arm-like parenchyma, (D) transversal view of aerial channel intercepted by commissural vascular bundle, (E) longitudinal view of aerial channel. ac - aerial channel, ap - arm-like parenchyma, cs - commissure, eb - extension of bundle sheath, ef - ensheathing fibre, ph - phloem, st - stoma, x - xylem.

cells have not been described in Bromeliaceae. The appearance of the concertina cells described here is similar to that described for two Caesalpinieae species (Curtis et al. 1996). A higher capacity for water storage, derived from their highly sinuous cell wall, was attributed to these cells (Curtis et al. 1996). Such possibility is a clearly desirable feature under non constant conditions of water supply; however, experimental data is necessary before we can attribute such a role for the concertina cells.

The data presented here suggests that classical anatomical differences described for sun and shade leaves (Björkman 1981) are less conspicuous in $N$. cruenta as several features varied as much within 
each leaf type as they varied between sun and shade leaves. Among the traits that were significantly different, we found that sun leaves were thicker in the apex portion due to the number of chlorenchyma cell layers. Thicker leaves due to a larger number of cell layers were described as typical of sun plants (Björkman 1981, Strauss-Debenedetti and Berlyn 1994). Nevertheless, the fact that shade leaves were thicker in the base apparently goes against these trends. However, the interpretation of anatomical traits is incomplete if architecture of the rosette is not taken into account. Shade leaves are nearly horizontal such that the base of the leaf is photosynthetic active. Such aspect is supported by the presence of stomata in this portion. In contrast, sun leaves are nearly vertical and the base of the leaf is not exposed to light, stomata are almost absent and trichomes are more abundant. Changes in the angle of the leaves in response to light is well described for more than 50 years (Pyykkö 1966). Tank-form bromeliads tend to restrict gas-exchange to the upper portion of the blade and water uptake to the base, which is usually submerged (Adams and Martin 1986, Reinert and Meirelles 1993). This seems more the case of sun plants than shade ones. Sun plants withhold water in the centre of the rosette as well as in between more external leaves. In contrast, shade plants mainly withhold water in the centre, because more external leaves do not overlap enough. More stomata in the apex of sun plants, such as observed here, was expected as described for other sun plants, in order to support larger photosynthetic rates (Givnish 1988).

Differences in crown architecture between plants growing under differing sun and shade in the forest understory were more relevant than those between species within the same environment (Valladares et al. 2002). The relatively subtle anatomical differences observed between sun and shade leaves of $N$. cruenta contrasts with the marked morphological differences between their sun and shade rosettes. The architecture of sun rosettes of $N$. cruenta mainly favours less light capture at the same time that reduces exposure of leaf surface and tank water surface to evaporation. Rosette traits of shade plants optimize light capture, without much regard to evaporation constraints. Such differences in the architecture probably result in less dramatic differences in light incidence at the tissue level of the sun and shade plants, which in turn may or may not translate into similar rates of photosynthesis. These questions open a new venue in our understanding of plant production in response to light in Bromeliaceae.

\section{RESUMO}

Plantas de sol e sombra são frequentemente distinguíveis por diversos aspectos anatômicos. Não obstante, propomos que entre bromélias-tanque, mudanças na arquitetura da roseta satisfazem os requerimentos que permitem habitar extremos de luminosidade. A bromélia-tanque, Neoregelia cruenta naturalmente coloniza microhabitats que variam da exposição direta ao sol, a ambientes sombreados sob o dossel da vegetação de restinga. Quantificamos aspectos anatômicos e morfológicos das folhas e rosetas de $N$. cruenta crescida sob sol e sombra. Células com paredes onduladas no parênquima aquífero são pela primeira vez descritas na família. No sol, as folhas são mais largas, menores e amareladas. $\mathrm{O}$ diâmetro da roseta é menos que a metade daquele de plantas de sombra. Folhas de sol se sobrepõem pela maior parte do seu comprimento, formando uma roseta cilíndrica que acumula água. Folhas de sombra somente se sobrepõem na base. A maioria dos aspectos anatômicos são similares sob ambas as condições de crescimento. Estômatos são ausentes na base de folhas de sol, provavelmente em função da limitação de trocas gasosas nessa região. Os dados sugerem que a habilidade de $N$. cruenta em aclimatar a condições de sol e sombra é melhor explicada por mudanças na arquitetura da roseta que por mudanças anatômicas.

Palavras-chave: Bromeliaceae, arquitetura de parte aérea, anatomia foliar, morfologia vegetal. 


\section{REFERENCES}

ADAMS WW AND MARTIN CE. 1986. Morphological changes accompanying the transition from juvenile (atmospheric) to adult (tank) forms in the Mexican epiphytes Tillandsia deppeana (Bromeliaceae). Am J Bot 73: 1207-1214.

BENZING DH. 1970. Foliar permeability and the absortion of mineral and organic nitrogen by certain tank bromeliads. Bot Gaz 131: 23-31.

BENZING DH. 1976. Bromeliad trichomes: structure, function and ecological significance. Selbyana 1: 330-348.

BJÖRKMAN O. 1981. Responses to different quantum flux densities. In: Lange OL, Osmond CB and Ziegler H (Eds), Encyclopedia of Plant Physiology I New Series. SpringerVerlag, Berlin, p. 57-107.

BONGERS F AND POPMA J. 1990. Leaf characteristics of the tropical rain forest flora of Los-Tuxtlas, Mexico. Bot Gaz 151: 354-365

BUKATSCH F. 1972. Bermkungen zur Doppelfarbung Astrablausafranina. Mikrokomos 61: 255.

CURTIS JD, LERSTEN NR AND LEWIS GP. 1996. Leaf anatomy, emphasizing unusual "concertina" mesophyll cells, of two east African legumes (Caesalpinoideae, Leguminosae). Ann Bot 78: 55-59.

DownS RJ. 1974. Anatomy and physiology. In: Smith LB and Downs RJ (Eds), Pitcairnioideae (Bromeliaceae), Flora Neotropica. Hafner Press, New York, p. 2-28.

FERNANDES J, CHALOUB RM AND REINERT F. 2002. Influence of nitrogen supply on the photoprotective response of Neoregelia cruenta under high and low light intensity. Funct Plant Biol 29: 757-762.

GIBSON AC. 1982. The anatomy of succulence. In: Ting IP and Gibbs M (Eds), Crassulacean acid metabolism. Am Soc Plant Physiol, Rockville, p. 1-30.

GivNisH TJ. 1988. Adaptation to sun and shade: a wholeplant perspective. Aust J Plant Physiol 15: 63-92.

HASLAM RP, BORLAND AM AND GRIFFITHS H. 2002. Shortterm plasticity of crassulacean acid metabolism expression in the epiphytic bromeliad, Tillandsia usneoides. Funct Plant Biol 29: 749-756.

KoHYAMA T AND HotTA M. 1990. Significance of allometry in tropical saplings. Funct Ecol 4: 515-521.

KRAUS JE AND ARDUIN M. 1997. Manual básico de métodos em morfologia vegetal. Edur Ed. Seropédica.

LACERDA LD AND HAY JD. 1982. Habitat of Neoregelia cruenta (Bromeliaceae) in coastal sand dune of Maricá, Brazil. Rev Biol Trop 30: 171-173.

LeE HSJ, Luttge U, Medina E, Smith JaC, Cram WJ, Diaz M, GRIFFThS H, Popp M, Schafer C AND STIMMEL K-H. 1989. Ecophysiology of xerophytic and halophytic vegetation of a coastal alluvial plain in northern Venezuela. III. Bromelia humilis Jacq., a terrestrial CAM bromeliad. New Phytol 111: 253-271.

LOESCHEN VS, MARTin CE, SMITH M AND EdER SL. 1993. Leaf Anatomy and $\mathrm{CO}_{2}$ recycling during Crassulacean Acid Metabolism in twelve epiphytic species of Tillandsia (Bromeliaceae). Int J Plant Sci 154: 100-106.
MANTOVANI A AND IGLESIAS RR. 2005. Quando aparece a primeira escama? Estudo comparativo sobre o surgimento de escamas de absorção em três espécies de bromélias terrestres. Rodriguesia 56: 73-84.

Mantuano DG, BARros CF AND SCARANO FR. 2006. Leaf anatomy variation within and between three "restinga" populations of Erythroxylum ovalifolium Peyr. (Erythroxylaceae). in Southeast Brazil. Rev Bras Bot 29: 209-215

MARTIN CE. 1994. Physiological ecology of the Bromeliaceae. Bot Rev 60: 1-82

Martin CE, MCLeod KW, EAdes CA ANd Pitzer AF. 1985. Morphological and physiological responses to irradiance in the CAM epiphyte Tillandsia usneoides L. (Bromeliaceae). Bot Gaz 150: 489-494.

Nelson EA AND SAGE RF. 2008. Functional constraints of CAM leaf anatomy: tight cell packing is associated with increased CAM function across a gradient of CAM expression. J Exp Bot 59: 1841-1850.

Nelson EA, Sage TL and Sage RF. 2005. Functional leaf anatomy of plants with crassulacean acid metabolism. Funct Plant Biol 32: 409-419.

PEARCY RW AND YANG W. 1998. The functional morphology of light capture and carbon gain in the redwood-forest understory plant, Adenocaulon bicolor Hook. Funct Ecol 12: $543-552$

Poorter L, KWAnt R, Hernandez R, MEdina E AND WERGER MJA. 2000. Leaf optical properties in Venezuelan cloud forest trees. Tree Physiol 20: 519-526.

PROENÇA SL AND SAJO MG. 2004. Estrutura foliar de espécies de Aechmea Ruiz \& Pav. (Bromeliaceae) do Estado de São Paulo, Brasil. Acta Bot Bras 18: 319-331.

PROENÇA SL AND SAJO MG. 2007. Anatomia foliar de bromélias ocorrentes em áreas de cerrado do Estado de São Paulo, Brasil. Acta Bot Bras 21: 657-673.

PYYKKÖ M. 1966. The leaf anatomy of East Patagonian xeromorphic plants. Ann Bot Fennici 3: 453-622.

Reinert F, Mattos EA, Maguas C AND GriffThS H. 2001. Effects of light and drought on CAM and on-line carbon discrimination in the bromeliad Neoregelia cruenta (R. Graham) L.B. Smith. In: Proceedings $12^{\text {th }}$ International Congress on Photosynthesis. Csiro Publishing Ed. Collingwood, p. 1-6.

REINERT F AND MEIRELles ST. 1993. Water acquisition strategy shifts in the heterophylous saxicolous bromeliad, Vriesea geniculata (Wawra) Wawra. Selbyana 14: 80-88.

REINERT F, Rocha JA, FERnANDES J AND Ribas L. 1998. Effect of changes in light and humidity on CAM activity in Tillandsia stricta Soland. (Bromeliaceae). Leandra 13: 7-15.

SCARANO FR, DUARTE HM, RÔÇAS G, BARRETO SMB, AMADO EF, REINERT F, WENDT T, LIMA HRP AND BARROS CF. 2002. Acclimatation or stress sympton? An integrated study of interspecific variation in the clonal plant Aechmea bromeliifolia, a widespread CAM tank-bromeliad. Bot J Linn Soc 140: 391-401.

SCATENA VL AND SEgECIN S. 2005. Anatomia foliar de Tillandsia L. (Bromeliaceae) dos Campos Gerais, Paraná, Brasil. Rev Bras Bot 28: 635-649. 
SMITH JAC, INGRAM J, TSIANTIS MS, BARKLA BJ, BARThOlOMEW DM, BetTEY M, PANTOJA O AND PENNINGTON AJ. 1996. Transport across the vacuolar membrane in CAM plants. In: Winter K and Smith JAC (Eds), Crassulacean Acid Metabolism: Biochemistry, Ecophysiology and Evolution. Springer-Verlag, Berlin, p. 53-71.

STRAUSS-DEBENEDETTI S AND BERLYN GP. 1994. Leaf anatomical responses to light in five tropical Moraceae of different successional status. Am J Bot 81: 1582-1591.

Tomlinson PB. 1969. Anatomy of the Monocotyledons. C. R. Metcalfe Ed., Oxford.

Valladares F, Skillman JB AND PeArCy RW. 2002. Convergence in light capture efficiencies among tropical forest understory plants with contrasting crown architectures: a case of morphological compensation. Am J Bot 89: 1275-1284.
VALLADARES F, WRIGHT SJ, LASSO E, KITAJIMA K AND PEARCY RW. 2000. Plastic phenotypic response to light of 16 congeneric shrubs from a Panamanian rainforest. Ecology 81: 1925-1936.

Winter K, Wallace BJ, Stocker GC AND ROKSANDiC Z. 1983. Crassulacean acid metabolism in Australian vascular epiphytes and some related species. Oecologia 57: 129-141. 